\title{
Optimal time of administration of fentanyl in reducing hemodynamic response in endotracheal intubation
}

\author{
Guntur Muhammad Taqwin'*, I Gusti Ngurah Artika², Sri Rahardjo² \\ ${ }^{1}$ Dr Soeselo District Hospital Slawi, Center Java, ${ }^{2}$ Department of Anesthesiology and \\ Reanimation, Faculty of Medicine/Dr Sardjito General Hospital, Universitas Gadjah Mada, \\ Yogyakarta
}

\begin{abstract}
Laryngoscopy and endotracheal intubations are frequently conducted in general anesthesia. However, it can stimulate symphatic and sympatoadrenal activities. Several non and pharmacological interventions have been used to reduce the symphatic stimulation. Fentanyl is one of the opioid drugs that frequently used to decrease the cardiovascular responses after the intubations. In order to obtain an optimal effect, fentanyl should be administered in appropriate time. This study was conducted to compare the time of fentanyl administration at 2, 5 and 7 minutes before endotracheal intubation to reduce hemodynamic responses. This was an obervational study with a prospective cohort design on patients who were going to undergo elective sugical using general anesthesia followed laryngoscopy intubation in Dr Sardjito General Hospital and met the inclusion and exclusion criteria. The patients were then divided into 3 groups i.e patients who received fentanyl $1.5 \mu \mathrm{g} / \mathrm{kg}$ body weight (BW) intravenously (IV) 2 minutes (Group A), 5 minutes (Group B) and 7 minutes (Group C) before laryngoscopy intubations. The hemodynmic responses including sistolic and diastolic blood pressure (SBP and DBP), mean arterial pressure (MAP), heart rate (HR) and rate pressure product (RPP) were monitored and recorded every 1 minute during 7 minutes period. The result showed that fentanyl administration 5 minutes before laryngeal intubation was more effective in the decrease hemodynamic response that those 2 and 7 minutes. Significantly different in SBP in 2, 3, 4 and 7 minutes observations was observed $(p<0.05)$. Furthermore, significantly different in MAP in 2, 3 and 4 minutes observation and in RPP in 1, 2, 3, 4 and 7 minute observation were also observed $(p<0.05)$. No significantly different was observed in HR during observation $(p>0.05)$. In conclusion, the administration of fentanyl $1.5 \mu \mathrm{g} / \mathrm{kg}$ BW IV at 5 minutes before intubation is more effective against hemodynamic responses in endotracheal intubation.
\end{abstract}

\section{ABSTRAK}

Laringoskopi dan intubasi endotrakhea sering dilakukan pada anestesi umum. Namun demikian, tindakan ini dapat memacu aktivitas simpatis maupun simpatoadrenal. Berbagai tindakan nonataupun farmaklogi telah digunakan untuk menurunkan pacuan simpatis. Fentanil merupakan obat opioid yang sering digunakan untuk menurunkan respon kardiovaskular setelah intubasi. Untuk memperoleh efek yang optimal, fentanil harus diberikan pada waktu yang tepat. Penelitian ini dilakukan untuk membandingkan waktu pemberian fentanil pada menit ke 2, 5 dan 7 sebelum intubasi endotrakhea dalam menurunkan respon hemodinamik. Penelitian ini merupakan penelitian observasional dengan rancangan kohort prospektif pada pasien yang akan menjalani bedah elektif dengan anestesia umum yang diikuti dengan intubasi laringoskopi di RSUP Dr Sardjito yang memenuhi kriteria inklusi dan eksklusi. Pasien dibagi menjadi 3 kelompok yaitu pasien yang menerima fenantil dosis $1,5 \mu \mathrm{g} / \mathrm{kg}$ berat badan intravena 2 menit (Group A), 5 menit (Group B) dan 7 menit (Group C) sebelum intubasi laringoskopi. Respon hemodinamik yang meliputi tekanan

\footnotetext{
* corresponding author: gunturtaqwin@ymail.com
} 


\begin{abstract}
darah sistolik dan diastolik (TDS adan TDD), rerata tekan arteri (RTA), denyut jantung dan rate pressure product (RPP) dimonitor dan dicatat setiap menit selama 7 menit. Hasil penelitian menunjukkan pemberian fentanil 5 menit sebelum intubasi laring lebih efektif menurunkan respon hemodinamik dibandingkan pemberian pada menit ke 2 dan 7. Perbedaan TDS secara nyata terlihat pada menit ke 2, 3, 4 dan 7 pengamatan $(p<0.05)$. Selanjutnya, perbedaan RTA secara nyata terlihat pada menit ke 2, 3 dan 4 dan perbedaan RPP secara nyata juga terlihat pada menit ke $1,2,3,4$ dan 7 pengamatan $(p<0.05)$. Tidak terdapat perbedaan nyata denyut nadi selama pengamatan ( $p>0.05$ ). Dapat disimpulkan, pemberian fentanil dosis $1,5 \mu \mathrm{g} / \mathrm{kg}$ BB IV pada menit ke 5 sebelum intubasi lebih efektif dalam menurunkan response hemodinamik pada intubasi endotrakhea.
\end{abstract}

Keywords: fentanyl - administration time - hemodynamic response - endotracheal intubation laryngoscopy

\section{INTRODUCTION}

Laryngoscopy and endotracheal intubation is a common intervention in general anesthesia. ${ }^{1}$ However, these interventions often cause side effects including excessive sympathetic and sympathoadrenal reflexes lead to increased blood pressure, heart rate and arrhythmia. The side effects are temporary and reversible which are harmless for healthy subjects. However, these side effects become serious problems for patients with previous risk factors such as hypertension, coronary arterial disease (CAD), cerebrovascular disease (CVD), and intracranial aneurysms..$^{2-5}$

Several factors that influence the onset of sympathetic stimulation due endotracheal intubation are identified such as the type and dose of induction drug, additional drugs administered before laryngoscopy intubation, the characteristics of the blade and endotracheal tube, the initial hemodynamic status, duration of performing intubation, the intubation operator's skills, as well as age and body weight of the patient. ${ }^{1,2}$ Moreover, several methods have been implemanted to prevent or reduce these cardiovascular responses including the deepening effect of the anesthesia ${ }^{6,7}$ and drugs administration such as local anesthetic either intravenously or topically (lidocaine) $)^{6-8}$, opioid such as fentanyl, alfentanyl and remifentany $1^{5,6,8}, \beta$-adrenergic blockers and vasodilators such as nitrogliserin, sodium nitroprusid ${ }^{7,9}$ and combination of those drugs. ${ }^{8}$ However, each of these methods has its own advantages and disadvantages.

Intravenous fentanyl is a drug that is frequently used in Dr. Sardjito General Hospital, Yogyakarta in addition to intravenous lidocaine. Recently, fentanyl has become popular among physician. It is not only effective in reducing the hemodynamic response caused by laryngoscopy and endotracheal intubation, but also has some advantages, as it serves as an analgesic preempetive during the surgery operation. Fentanyl has a rapid and short-acting effect. ${ }^{1}$ The high potential of the drug is due to its high level of solubility in fat. It is distributed into fat and muscle tissues. Plasma concentration of about 1-2 $\mathrm{ng} / \mathrm{mL}$ is required to achieve the effect of analgesia, which can be achieved by administrating fentanyl $2-8 \mu \mathrm{g} / \mathrm{kgBW}$ (body weight). ${ }^{10}$ The maximum plasma concentration reaches within the first 5 minutes. The plasma fentanyl concentration decreases to $20 \%$ of its initial concentration slowly for about 10-20 minutes. ${ }^{9,11}$ The EEG response is parallel to the concentration of fentanyl in the brain. ${ }^{10}$ However, due to the effect is slow, ideally 
fentanyl should be administered within \pm 5 minutes before giving any intervention causing stimulations of the organs.

The aim of the study was to compare the effectiveness of the administration of $1.5 \mathrm{~g} /$ kgBW fentanyl two, five and seven minutes before endotracheal intubation in order to reduce the hemodynamic responses. If the fentanyl administration five minutes before the endotracheal intubation is more effective to reduce the hemodynamic responses than two or seven minutes it can be used as an alternative in the airway management.

\section{MATERIALS AND METHODS}

\section{Subjects}

This was an obervational study with a prospective cohort design to evaluate the effect of time administration of fentanyl in reducing hemodynamic response in endotracheal intubation. Subjects of study were patients who were going to undergo elective sugical procedures using general anesthesia techniques followed laryngoscopy intubation in Department of Anesthesiology and Reanimation, Dr Sardjito General Hospital and met the inclusion and exclusion criteria. The inclusion criteria were 1) male or female patients aged $18-55$ years, 2) physical status ASA I-II, 3) going to conduct elective surgery procedure other than neurological surgery and ceasarean section under general anesthesia and oral intubation, 4) BMI $>20-30 \mathrm{~kg} / \mathrm{m} 2$, 5) Malampati grade I-II, 6) vital signs within normal limits, and 7) agreed to participate in the study. The exclusion criteria were 1) patients with cardiovascular system disorders, such as: a) congenital heart defects, b) a history of hypertension, c) ischemic heart disease, and d) heart failure, 2) patients with central nervous system disorders, such as: a) the high intracranial pressure, and b) mass or intracranial hemorrhage, 3) patients with impaired renal function, 4) patients with pregnancy, 6) patients with hypoalbumin $<3 \mathrm{~g} /$ $\mathrm{dL}, 7$ ) having history of asthma, or 8) having history of allergy to fentanyl.

\section{Procedure of study}

The study would be conducted after obtain the approval from Medical and Health Research Ethics Committee, Faculty of Medicine, Universitas Gadjah Mada, Yogyakarta. Subjects or patients who were going to undergo elective surgical procedures followed laryngoscopy intubation were given explanation concerning the background, objectives, benefit, and procedure of the study. Patients who fulfilled the inclusion and exclusion criteria as well as willing to be involved in the study would sign an inform consent. The characteristics of patients were taken before surgical procedures conducted. The patients were then divided into three groups. Group A was the subjects who received fentanyl $1.5 \mathrm{~g} / \mathrm{kg}$ body weight (BW) intravenously (IV) 2 minutes before laryngoscopy intubation, Group B was the subjects who received fentanyl $1.5 \mathrm{~g} / \mathrm{kgBW}$ IV 5 minutes before laryngoscopy intubation, and Group $C$ was the subjects who received fentanyl $1.5 \mathrm{~g} / \mathrm{kgBW}$ IV 7 minutes before laryngoscopy intubation. The procedure of the study was as follows: Patients would fast for 6 hours before the surgery, fluid requirements during fasting was corrected before the surgery using Ringers Lactate solution $2 \mathrm{~mL} / \mathrm{kgBW} /$ hour. Patients were not given any premedication, and prepared according to the routine procedures. After patients arrival in the operation room, hemodynamic measurement, systolic and diastolic pressure (SBP and DBP), mean arterial pressure (MAP), heart rate (HR) and rate pressure product (RPP) were measured. The 
mean value of these variables was used as the basic data for the study. Three minutes after the preoxigenation, propofol (1-2 $\mathrm{mg} / \mathrm{kgBW})$ was given for about 30 seconds, continued with the administration of rocuronium $0.6 \mathrm{mg} / \mathrm{kgBW}$ to facilitate the intubation. During the induction period as indicated with the lost of eyelashes reflex, manual ventilation of $12 \mathrm{x} /$ minute with $1 \mathrm{vol} \%$ isoflurane with $50 \% \mathrm{~N}_{2} \mathrm{O}$ in oxygen were given for 5 minutes. Laryngoscopy and intubation were then performed. According to each group, fentanyl $1.5 \mathrm{mg} / \mathrm{kgBW}$ was blindly administered two or five or seven minutes before the laryngoscopy intubation. The researcher did not know, however the research assistant knowed the administration time of the fentanyl. After the placement of the endotracheal tube, anesthesia was maintained with 1 vol \% isofluran with $50 \% \quad \mathrm{~N}_{2} \mathrm{O}$ in oxygen. Hemodynamic response of each group of fentanyl administration after the laryngoscopy and intubation intervention was monitored and recorded. During the study, the appearance of side effects such as allergic reactions, cough, hypotension, hypertension, tachycardia, bradycardia, and arryhthmia were also monitored and recorded. The subject would be excluded from the study if the laryngoscopy and intubation were performed within more than 60 seconds or there were any existence of side effects which require further intervention and treatment.

\section{Statistical analysis}

Descriptive and analytical analysis were used data analysis. Paired t-test was used to compare numerical variables for each of the paired groups whereas independent t-test was used to compare of mean between groups. Chisquare was used to compare nominal variables. $\mathrm{p}$ value $<0.05$ with $95 \%$ confidence interval was considered as significant.

\section{RESULTS}

Charateristics of subjects of each group are presented in TABLE 1. It appeared that the characteristics subjects of three groups were not significantly different $(p>0.05)$. The haemodynamics parameters including SBP, DBP, MAP, HR and RPP between three groups before laryngeal intubation were also not significantly different $(\mathrm{p}>0.05)$.

The hemodynamic response after fentanyl administration 2, 5 and 7 minutes before laryngeal intubation including SBP, MAP, HR and RPP are presented in FIGURE 1, 2, 3 and 4 , respectively. The results showed that the fentanyl administration 5 minutes before laryngeal intubation (Group B) was more effective in the decrease hemodynamic response that those 2 (Group A) and 7 minutes (Group C) before laryngeal intubation. Significantly different in SBP in 2, 3, 4 and 7 minutes observations was observed $(p<0.05)$. Furthermore, significantly different in MAP in 2, 3 and 4 minutes observation and in RPP in 1, 2, 3, 4 and 7 minute observation were also observed $(p<0.05)$. No significantly different was observed in HR during observation $(\mathrm{p}>0.05)$. 
TABLE 1. Characteristics of subjects

\begin{tabular}{|c|c|c|c|c|}
\hline Variables & Group A & Group B & Group C & $\mathbf{p}$ \\
\hline Age (year) & $42.35 \pm 10.26$ & $39.44 \pm 14.02$ & $36.41 \pm 14.50$ & 0.418 \\
\hline Weight (kg) & $54.82 \pm 8.91$ & $51.65 \pm 7.40$ & $53.82 \pm 8.38$ & 0.522 \\
\hline Height $(\mathrm{cm})$ & $156.00 \pm 8.02$ & $159.59 \pm 6.74$ & $158.29 \pm 8.44$ & 0.401 \\
\hline BMI & $22.41 \pm 2.25$ & $20.34 \pm 3.06$ & $21.38 \pm 2.56$ & 0.060 \\
\hline $\mathrm{SBP}(\mathrm{mmHg})$ & $129.53 \pm 14.78$ & $119.71 \pm 8.20$ & $121.59 \pm 13.86$ & 0.065 \\
\hline $\mathrm{DBP}(\mathrm{mmHg})$ & $76.29 \pm 4.75$ & $77.71 \pm 7.47$ & $76.04 \pm 7.24$ & 0.354 \\
\hline MAP (mmHg) & $94.06 \pm 5.56$ & $91.71 \pm 6.78$ & $91.88 \pm 7.53$ & 0.273 \\
\hline $\mathrm{HR}$ (x/minutes) & $82.44 \pm 14.01$ & $76.59 \pm 7.30$ & $78.65 \pm 11.01$ & 0.143 \\
\hline RPP & $10749 \pm 2259$ & $9164 \pm 1019$ & $9304 \pm 1713$ & 0.256 \\
\hline \multicolumn{5}{|l|}{ Sex: n $(\%)$} \\
\hline - Male & $9(52.9 \%)$ & $9(52.9 \%)$ & $9(52.9 \%)$ & \multirow{2}{*}{1.000} \\
\hline - Female & $8(47.1 \%)$ & $8(47.1 \%)$ & $8(47.1 \%)$ & \\
\hline \multicolumn{5}{|l|}{ Physical status: n (\%) } \\
\hline - ASA I & $9(52.9 \%)$ & $8(47.1 \%)$ & $12(70.6 \%)$ & \multirow{2}{*}{0.354} \\
\hline - ASA II & $8(47.1 \%)$ & $9(52.9 \%)$ & $5(29.4 \%)$ & \\
\hline \multicolumn{5}{|l|}{ Education: $n(\%)$} \\
\hline - Elementary School & $3(17.6 \%)$ & $3(17.6 \%)$ & $3(17.6 \%)$ & \multirow{4}{*}{0.996} \\
\hline - Junior High School & $2(11.8 \%)$ & $3(17.6 \%)$ & $2(11.8 \%)$ & \\
\hline - Senior High School & $10(58.8 \%)$ & $9(52.9 \%)$ & $9(52.9 \%)$ & \\
\hline - Higher Education & $2(11.8 \%)$ & $2(11.8 \%)$ & $3(17.6 \%)$ & \\
\hline
\end{tabular}

Group A, B and C were fentanyl $1.5 \mathrm{~g} / \mathrm{kg} B W I V$ administration 2, 5 and 7 minutes before laryngeal intubation, respectively. SBP: systolic blood pressure, DBP: diastolic blood pressure, MAP: mean arterial pressure, HR: heart rate, RPP: rate presure product. $p<0.05$ : statistically significant difference

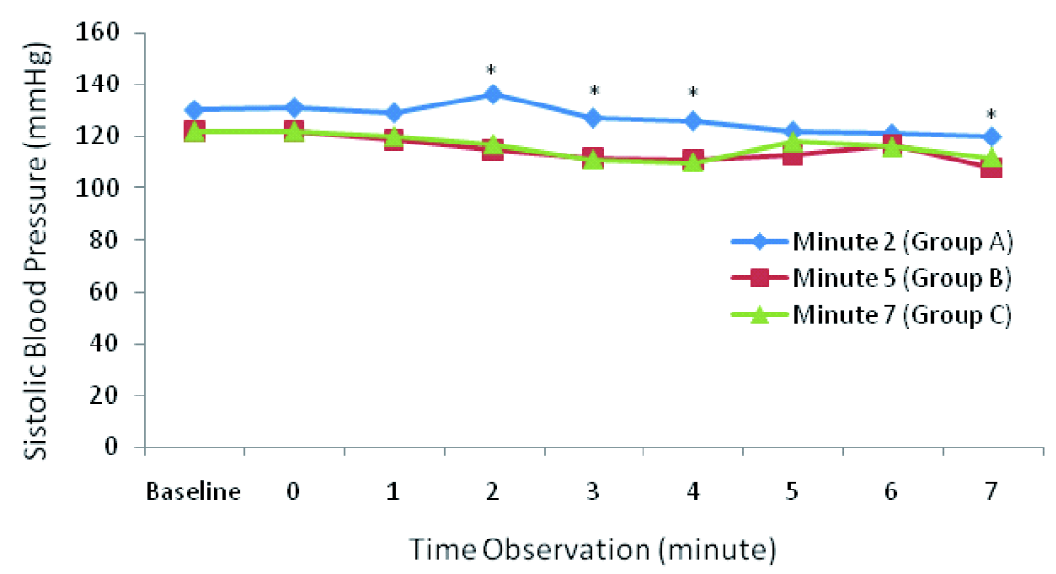

FIGURE 1. Changes in SBP in 3 research groups during 7 minutes observation. * Significantly different $(\mathrm{p}<0.05)$. 


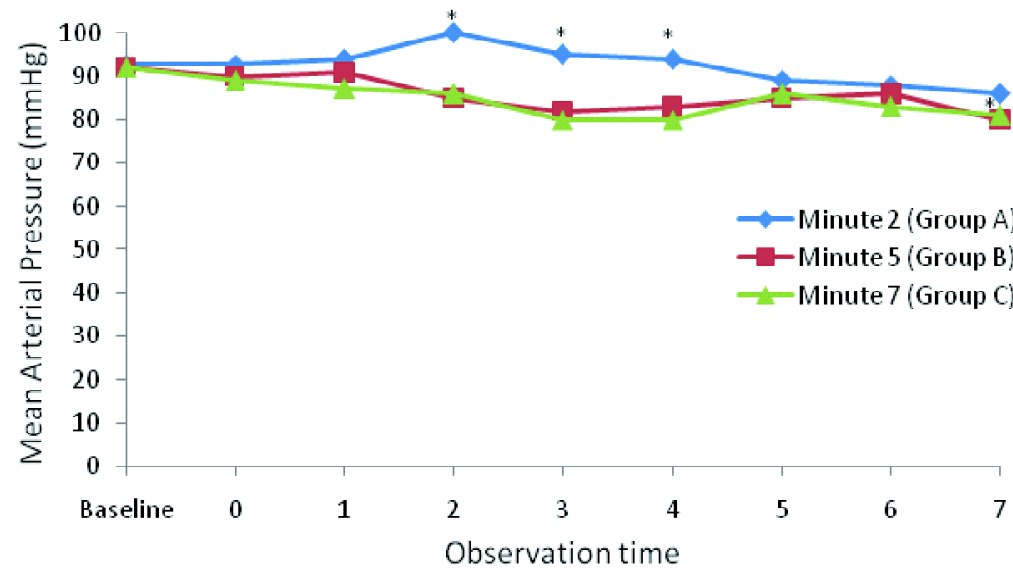

FIGURE 2. Changes in MAP in 3 research groups during 7 minutes observation. *Significantly different $(\mathrm{p}<0.05)$

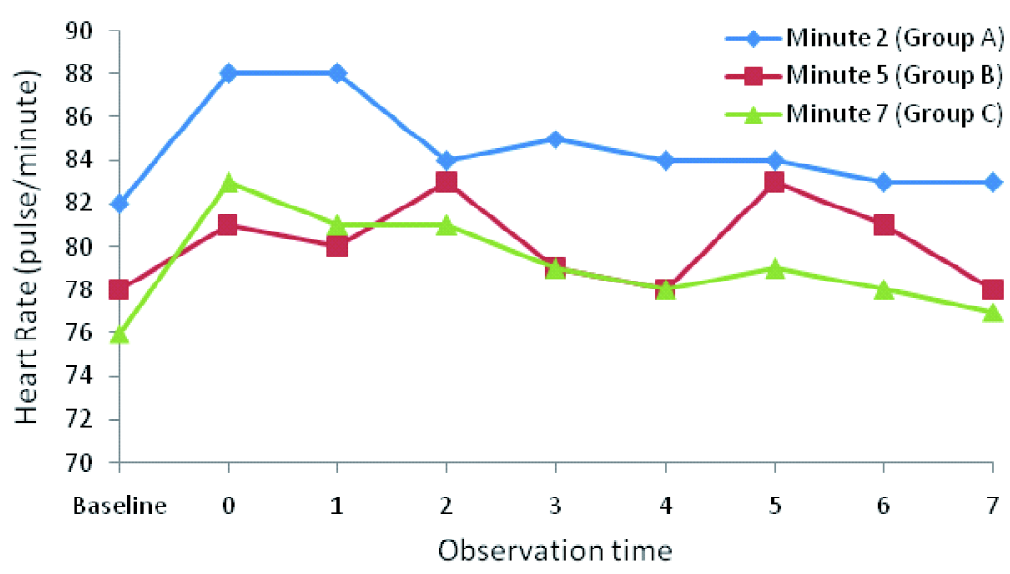

FIGURE 3. Changes in HR in 3 research groups during 7 minutes observation. *Significantly different $(\mathrm{p}<0.05)$.

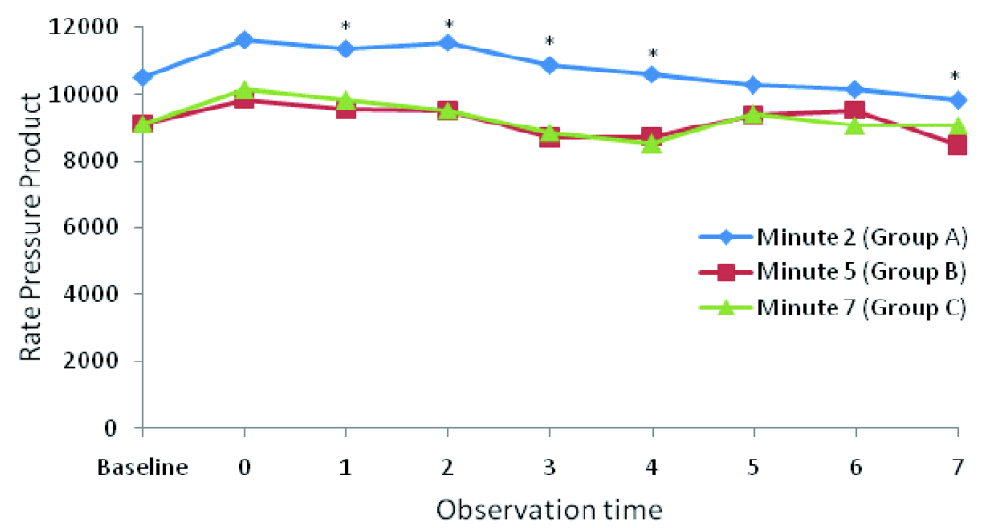

FIGURE 4. Changes in RPP in 3 research groups during 7 minutes observation. *Significantly different $(\mathrm{p}<0.05)$. 
Change in RPP of the 3 groups during 7 minutes observation after laryngeal intubation are presented in TABLE 2 . No patients with risk of miocard $(\mathrm{RPP} \leq 12,000)$ were observed in Group B, whereas patients with riks of miocard (RPP 15,000-20,000) were observed in Group A and C.

TABLE 2. Change in RPP of the 3 groups after laryngoscopy intubation from minute 0 to 7

\begin{tabular}{|c|c|c|c|c|c|c|}
\hline \multirow{2}{*}{ RPP variables } & \multicolumn{2}{|c|}{ Group A } & \multicolumn{2}{|c|}{ Group C } & \multicolumn{2}{|c|}{ Group B } \\
\hline & $\mathrm{n}$ & $\%$ & $\mathrm{n}$ & $\%$ & $\mathrm{n}$ & $\%$ \\
\hline \multicolumn{7}{|l|}{ Minute 0} \\
\hline$\cdot \leq 12,000$ & 12 & 70.6 & 15 & 88.2 & 13 & 76.5 \\
\hline - $>12,000-15,000$ & 3 & 17.6 & 2 & 11.8 & 3 & 17.6 \\
\hline - $>15,000 \quad 20,000$ & 2 & 11.8 & - & & 1 & 5.9 \\
\hline \multicolumn{7}{|l|}{ Minute 1} \\
\hline - $\leq 12,000$ & 9 & 52.9 & 15 & 88.2 & 15 & 88.2 \\
\hline - $>12,000-15,000$ & 8 & 47.1 & 2 & 11.8 & 2 & 11.8 \\
\hline - $>15,000-20,000$ & - & . & - & & - & - \\
\hline \multicolumn{7}{|l|}{ Minute 2} \\
\hline - $\leq 12,000$ & 7 & 41.2 & 17 & 100 & 15 & 88.2 \\
\hline - $>12,000-15,000$ & 8 & 47 & - & - & 2 & 11.8 \\
\hline - $>15,000-20,000$ & 2 & 11.8 & - & - & - & - \\
\hline \multicolumn{7}{|l|}{ Minute 3} \\
\hline$\cdot \leq 12,000$ & 13 & 76.5 & 16 & 94.1 & 16 & 94.1 \\
\hline - $>12,000-15,000$ & 3 & 17.6 & 1 & 5.9 & 1 & 5.9 \\
\hline - $>15,000-20,000$ & 1 & 5.9 & - & - & - & - \\
\hline \multicolumn{7}{|l|}{ Minute 4} \\
\hline$\cdot \leq 12,000$ & 14 & 82.4 & 15 & 88.2 & 17 & 100 \\
\hline - $>12,000 \quad 15,000$ & 3 & 17.6 & 2 & 11.8 & - & \\
\hline \multicolumn{7}{|l|}{ Minute 5} \\
\hline$\cdot \leq 12,000$ & 12 & 70.6 & 13 & 76.5 & 15 & 88.2 \\
\hline - $>12,000-15,000$ & 5 & 29.4 & 4 & 23.5 & 2 & 11.8 \\
\hline \multicolumn{7}{|l|}{ Minute 6} \\
\hline$\cdot \leq 12,000$ & 12 & 70.6 & 14 & 82.4 & 15 & 88.2 \\
\hline - $>12,000-15,000$ & 5 & 29.4 & 3 & 17.6 & 2 & 11.8 \\
\hline \multicolumn{7}{|l|}{ Minute 7} \\
\hline$\cdot \leq 12,000$ & 15 & 88.2 & 17 & 100 & 17 & 100 \\
\hline$\cdot>12,000-15,000$ & 1 & 11.8 & & & & \\
\hline
\end{tabular}

Group $A, B$ and $C$ were fentanyl $1.5 \mathrm{~g} / \mathrm{kg} \mathrm{BW} \mathrm{IV} \mathrm{administration} \mathrm{2,} 5$ and 7 minutes before laryngeal intubation, respectively. $R P P \leq 12,000$ : normal value; $R P P>12,000$ 15,000: safe normal value of RPP in normal patients without heart abnormalities; RPP $\geq 12,000$ : in patients with coronary artery disease started to experience miocard ischemic; $R P P \geq 20,000$ : in patients without coronary artery disease started to experience miocard ischemic. 


\section{DISCUSSION}

This study was conducted to compare the effectiveness of fentanyl $1.5 \mathrm{~g} / \mathrm{kgBW}$ administration at 2, 5 and 7 minutes before endotracheal intubation to reduce hemodynamic responses including SBP and DBP, HR, MAP and RPP. The fenantyl administration $1.5 \mathrm{~g} /$ $\mathrm{kgBW}$ at 5 minute before laryngal intubation was proven to be more effective compare to those at 2 or 7 minutes before laryngal intubation indicating that this time of fenantyl administration was more effective in reducing hemodynamic responses. Therefore, it could be used as an alternative in airway management.

In laryngoscopic endotracheal intubation, the increase in blood pressure occurred as hemodynamic response that started 5 seconds after intubation. It reached the peak level in 1-2 minutes and then returned to endotracheal intubation levels within 5 minutes. In healthy subjects, the endotracheal intubation can increase SBP and DBP of 53 and $34 \mathrm{mmHg}$, respectively. In addition, it also increase heart rate by \pm 23 beats/minutes. ${ }^{12,13}$

In this study, premedications were not administered in orde to avoid or minimize the effects the premedications on patients' hemodynamic status. Therefore, it was expected the change in patients' hemodynamic status caused by fentanyl administration itself. However, the increase HR and RPP of some patients were observed and it might be caused by patient anxiety. The characteristics of subjects were not significantly different, therefore the 3 research groups could be well compared, and the results were considered being not affected by patients' characteristics.

The procedures of laryngoscopy and endotracheal intubation will lead to increased sympathetic stimulation due to pressure pain on oropharynx caused by laryngoscope edge or endotracheal tube. ${ }^{1,7,12}$ This pain response increases the efferent nerve reflex in sympathetic nervous system and leads to increased sympathetic impulse which will lead to secretion of adrenaline and noradrenaline from the adrenal glands. These hormones will increase blood pressure and heart rate. ${ }^{14}$ Stronger and longer stimulation will lead to increased hormone secretion, and this may lead to the peaking blood pressure and heart rate. ${ }^{6}$ These hemodynamic effects are dangerous for patients since these may lead to hypertension, tachycardia, disrhytmia, and others. Some techniques had been used to manage the hemodynamic responses. One of them is the administration of intravenous fentanyl before propofol induction. Besides effective in reducing hemodynamic responses in the procedure of laryngoscopic endotracheal intubation, fentanyl also provides some advantages such as being a preemptive analgetic especially when a surgery is planned to be carried out. Peak plasma concentration of fentanyl could be achieved in the first 5 minutes, as the fentanyl serum level decreases to $20 \%$ from previous serum level, which then keep decreasing relatively slowly for approximately 10-20 minutes. The onset of fentanyl is $30-60$ seconds and its duration is $30-60$ minutes..$^{9,11}$

The reason for comparing the time of fentanyl $1.5 \mathrm{~g} / \mathrm{kgBW}$ administration at 2, 5 and 7 minutes before endotracheal intubation was to reduce hemodynamic responses because the peak of plasma fentanyl concentration within 3-5 minutes. First 5 minutes after administration, plasma fentanyl concentration decrease slowly about $20 \%$ during about 20 minutes. Therefore, fentanyl $1.5 \mathrm{~g} / \mathrm{kgBW}$ administration at 7 minutes was chosen as one of 3 study groups. Whereas, fentanyl $1.5 \mathrm{~g} / \mathrm{kgBW}$ administration at 2 minute was chosen as one other of 3 study group because the onset of fentanyl was achieved. However, it had not achieved yet its peak effect against the hemodynamic responses. The 
increase in blood pressure occurred 5 seconds and reached its peak response between 1-2 minutes after endotracheal intubation.$^{9,11}$

The fentanyl administration in appropriate dose and time will give optimal duration and reduce the adverse effects. The appropriate dose of fentanyl against the hemodynamic responses has not been reported. However, the appropriate time of fentanyl administration has been reported by some authors i.e. 1-10 minutes before intubation. The results of this study was in line with study conducted Seong-Hoon et al. ${ }^{8}$ showing that fentanyl $2 \mathrm{~g} / \mathrm{kgBW}$ IV administration at 5 minutes before intubation was effective to alleviate hemodynamic responses including BP and HR. However, fentanyl administration at 1 and minutes before intubation did not provide protection in the increase of BP and HR.

Change in RPP was observed in 3 groups of study. The RPP value after the administration of fentanyl $1.5 \mathrm{~g} / \mathrm{kg} \mathrm{BW}$ IV at 5 minutes before intubation was 12,000 during 7 minutes observation. However, on administration of fentanyl at 2 minutes before intubation, 2 (11.8\%) patients had a RPP value $>15,000$ and on administration of fentanyl at 7 minutes before intubation, $1(5,9 \%)$ patient had a RPP value $>$ 15,000 . It is reported that patients with a RPP value $>12,000$ have risk of miocard ischemia.

\section{CONCLUSION}

In conclusion, the administration of fentanyl $1.5 \mu \mathrm{g} / \mathrm{kg} \mathrm{BW}$ IV at 5 minutes before endotracheal intubation is more effective against hemodynamic responses compare to those at 2 and 7 minutes before intubation.

\section{ACKNOWLEDGEMENTS}

We would like to thank Head of Department of Anesthesiology and Reanimation, Faculty of Medicine/Dr Sardjito General Hospital,
Universitas Gadjah Mada, Yogyakarta for their support in this study. We would also like to thank all patients who have participated in this study.

\section{REFERENCES}

1. Stone DJ, Gal TJ. Airway management. In: Miller RD editor. Anesthesia $4^{\text {rd }}$ ed. Philadelphia: Churchill Livingstone, 2000: 1414-48.

2. Hagberg CA, Georgi R and Krier C. Complications of managing the airway. In: Hagber CA editor. Benumof's air ways management: principle and practices. Philadelphia: Mosby-Elsevier, 2007: 1181-218.

3. Kanchi M, Nair HC, Banakal S, Murthy K, C. Haemodynamic response to endotracheal intubation in coronary artery disease: Direct versus video laryngoscopy. Indian J Anaesth 2011; 55(3):260-5.

4. Sengupta P, Sesler DI, Maglinger P, Wells S, Vogt A, Durrani J, Wadhwal A. Endotracheal tube cuff pressure in three hospitals, and the volume required to produce an appropriate cuff pressure. BMC Anesthesiology 2004; 4(1):8. Doi:10.1186/ 1471-2253-4-8.

5. Koichi T, Yuji M, Osamu K. Tracheal lidocain attenuates the cardiovascular response to endetracheal intubation. Canadian Journal of Anaesthesia, 2001; 48(8):732-4.

6. Flemming DC, Orkin FK, Kirb RR. Hazards of tracheal intubation. In: Nikolaus G, Robert RK editors. Complications in anesthesiology, $2^{\text {nd }}$ edition. New York: Lippincott-Raven; 1996: 22937.

7. Mallick A, Klein H, Mosse E. Prevention of cardiovascular response to tracheal intubation. $\mathrm{Br}$ J Anesth 1996; 77(2):296-77.

8. Seong-Hoon K, Dong-Chan K, Yong-Jin H. Small dose fentanyl: optimal time of injection for blunting the circulatory responses to tracheal intubation. Anaesth Analg 1998; 86(3):658-61.

9. Bisri T, Himendra W. Neurofarmakologi dalam Neuroanasthesi. Edisi 1. Bandung: Bagian anestesiologi dan Perawatan Intensif, FK UNPAD; 2000: 11-42.

10. Sear JW. Recent advances and developments in the clinical use IV opioids during the perioperative period. Br J Anaesth 1998; 81(1):38-50.

11. Stoelting RK. Opioid agonist and antagonists. In: Stoelting RK editor. Pharmacology and 
physiology in anesthetic practice, 4th edition. Philadelphia: Lippincott Williams \& Wilkins, 2006: 77-112.

12. Shribman AJ, Smith G, Achola KJ. Cardiovascular and cathecolamine responses to laryngoscopy with and without tracheal intubation. Br J Anaesth 1987; 59(3):295-9.
13. Henderson J. Tracheal intubation of adult patient. In: Caldent $\mathrm{F}$ and Pearce $\mathrm{A}$ editors. Core topics in airway management. New York: Cambridge University Press, 2005: 69-80.

14. Marwoto, Purwoko, Achmadi A. Perbandingan efek verapamil dan lidokain intravena terhadap respon kardiovaskuler pada tindakan laringoskopi intubasi. Anesthesia Crit Care. 2002; 23:10-18. 